УДК 343.9 (091)

DOI 10.18101/2658-4409-2020-1-16-25

\title{
ИСТОРИЧЕСКИЕ АСПЕКТЫ КРИМИНАЛИЗАЦИИ СОЗДАНИЯ, РУКОВОДСТВА И УЧАСТИЯ В ПРЕСТУПНЫХ СООБЩЕСТВАХ, ОРГАНИЗАЦИЯХ И ИНЫХ ОБЪЕДИНЕНИЯХ
}

\section{(C) Мондохонов Андрей Николаевич}

кандидат юридических наук, первый заместитель прокурора

Республики Хакасия, Прокуратура Республики Хакасия

Россия, 665017, г. Абакан, ул. Чертыгашева, 80

E-mail: andrmon1@yandex.ru

В статье автор выделяет исторические аспекты и этапы криминализации создания, руководства и участия в преступных сообществах, организациях и иных объединениях на фоне эволюции уголовно-правового института соучастия в преступлении. На первом этапе законодатель выделил преступления, совершенные одним лицом, и преступления, совершенные в составе группы лиц. На втором этапе произошло выделение различных видов преступных групп и объединений (скоп, шайка, банда, заговор). Третий этап характеризовался установлением критерия разграничения преступных объединений в виде цели их создания. На четвертом этапе сформировался современный институт соучастия в преступлении, на основе которого криминализирована организация преступного, террористического и экстремистского сообществ, а также террористической, экстремистской и некоммерческой организаций и иных объединений (банд, незаконных вооруженных формирований).

Ключевые слова: преступные объединения; организация; сообщество; соучастие; организованная группа; шайка; банда.

\section{Для цитирования}

Монхондонов А. Н. Исторические аспекты криминализации создания, руководства и участия в преступных сообществах, организациях и иных объединениях // Вестник Бурятского государственного университета. Юриспруденция. 2020. Вып. 1. С. 16-25.

История становления и развития института соучастия в преступлении в отечественном уголовном законодательстве подробно исследовалась в теории уголовного права. Вместе с тем в современных условиях особый интерес представляет анализ эволюции уголовно-правовых норм, предусматривающих ответственность за создание преступных объединений, руководство ими и участие в них. 
A. Н. Монхондонов. Исторические аспекты криминализации создания, руководства и участия в преступных сообществах, организациях и иных объединениях

Следует заметить, что в исторических памятниках уголовного права не формулировались понятие, виды и формы соучастия, правила квалификации деяний соучастников, тем не менее в них последовательно реализовывался принцип повышенной общественной опасности групповых преступлений.

Например, в качестве особенности законодательного памятника начала XI — конца XIII в. Русской Правды, в которой впервые упоминалось о совместном совершении преступления, следует отметить одинаковую ответственность всех соучастников (ст. 41 Пространной редакции Русской Правды) [3, с. 98]. Равная ответственность «любого количества» соучастников, участвовавших в причинении побоев «любому числу» потерпевших, закреплялась и в Псковской судной грамоте (ст. 120) [3, с. 331-343].

До XVI в. в законодательных актах, в том числе Судебниках 1497 г. и 1550 г., наблюдались попытки выделения видов соучастников, а также прикосновенных к преступлениям укрывателей, недоносителей, попустителей, лиц, не оказавших помощь властям.

Вместе с тем в сборнике постановлений церковно-земского собора, известном как Стоглав (1551г.), впервые упомянуто «чинение заговора» (гл. 69) [4, с. 344-349], что возможно рассматривать в качестве начального этапа развития отечественного уголовного законодательства о преступных объединениях.

Только в Соборном уложении 1649 г. получили развитие признаки соучастия, его формы (скоп, заговор) и виды соучастников (исполнители, подстрекатели, пособники) [2, с. 49].

В научной литературе, посвященной вопросам соучастия, наиболее часто цитируется ст. 198 Соборного уложения, в которой указано: «А будет кто придет к кому-нибудь на двор насильством, скопом и заговором, умысел воровски, и учинит над тем, к кому он придет, или над его женою, или над детьми, или над людьми смертное убойство, а сыщется про то допряма, и того, кто такое смертное убойство учинит, самого казнити смертию же, а товарищев его всех бити кнутом и сослати, куды государь укажет» [5, с. 134].

При толковании данной формулы совершения преступления несколькими лицами, на наш взгляд, следует учитывать следующие важные моменты. Во-первых, под скопом понимается устаревшее юридическое понятие - «участие в преступном деянии без предварительного соглашения, соучастие» ${ }^{1}$. Иными словами, это своего рода антоним понятия «заговор», под которым понимается «тайное соглашение нескольких лиц о

\footnotetext{
${ }^{1}$ Скоп // Викисловарь: Свободная энциклопедия: сайт. URL: https://ru.wiktionary. org/wiki/скоп (дата обращения: 27.07.2019).
} 
совместных действиях против кого-либо, чего-либо для достижения каких-либо целей» ${ }^{1}$. Вместе с тем в данной трактовке заговора определяющим является именно факт соглашения о совместных организованных действиях, то есть предварительный сговор. Поэтому, исходя из контекста исследуемой статьи Уложения и толкования понятий «скоп» и «заговор», последние в большей степени соответствуют таким формам соучастия в действующем российском уголовном законодательстве, как группа лиц и группа лиц по предварительному сговору, и являются видами преступных объединений.

Во-вторых, в ретроспективе российских юридических памятников понятия «скоп» и «заговор» использовались вплоть до начала XX в. Например, в Уложении о наказаниях уголовных и исправительных 1845 г. $^{2}$, в котором систематизированы передовые на тот период достижения уголовно-правовой науки, в том числе касающиеся института соучастия и преступных объединений, ответственности за совершение преступлений скопом и в заговоре (ст. 271), тайным обществом (ст. 347-353) или шайкой (ст. 924, ч. 2 ст. 1613).

Как видим, скоп и заговор законодатель относил к разновидностям преступной группы, которым в современном уголовном законодательстве соответствуют группа лиц и группа лиц по предварительному сговору, в то время как тайное общество и шайку — к разновидностям преступных объединений.

В XVIII-XX вв. значительное внимание российского законодательного органа уделялось криминализации деятельности «обществ», в том числе тайных, могущих причинить вред интересам государства и «способных посеять смуту», что повлекло их криминализацию в Уставе благочиния или полицейском 1782 г. [6] и Своде законов Российской империи 1842 г., а в дальнейшем в Уложении о наказаниях уголовных и исправительных в редакциях 1845 и 1867 гг. ${ }^{3}$ В соответствии с положениями этих законов наказанию подлежали как лица, являвшиеся основателями и руководителями (начальниками) тайных обществ, члены таких обществ, имевшие представление о целях деятельности последних, так и лица, знавшие о таких обществах и не сообщившие о них правительству при наличии возможности сообщить об этом.

1 Заговор // Там же. URL: https://ru.wiktionary.org/wiki/заговор (дата обращения: 27.07.2019).

2 Уложение о наказаниях уголовных и исправительных. СПб. : Тип. 2 отд-ния Собств. Е. И. В. канцелярии, 1845.

${ }^{3}$ Уложение о наказаниях уголовных и исправительных, с приведением статей других томов Свода законов, на которые сделаны ссылки и указания в этом уложении (изд. 1866 г.). Неофиц. изд. М. : тип. Шюман и Глушкова, 1867. 
A. Н. Монхондонов. Исторические аспекты криминализации создания, руководства и участия в преступных сообществах, организациях и иных объединениях

Следует заметить, что в указанных нормативных правовых актах при криминализации деятельности обществ впервые была введена ответственность за сам факт их создания, руководства ими и участия в них, что является определяющим признаком преступных объединений в уголовном законодательстве.

В Уголовном уложении 1903 г. криминализировано участие в мятежническом сообществе, созданном в целях насильственного посягательства на изменение образа правления или порядка наследия престола или на отторжение от России какой-либо ее части ${ }^{1}$. В качестве квалифицирующих признаков выступали наличие в распоряжении такого сообщества средств для взрыва или склада оружия и совершение насильственного посягательства. Составление заговора, вступление в уже составившийся заговор и попытка вовлечения кого-либо в сообщество, даже неудавшаяся, также признавались участием в мятежническом сообществе.

Сравнительный анализ позволяет провести аналогию между признаками мятежнического сообщества и террористического сообщества (ст. 205 УК), т. е. устойчивой группой лиц, заранее объединившихся в целях приготовления или совершения преступлений, предусмотренных ст. 278 и 279 УК.

Подобные «мятежнические сообщества» были поставлены вне закона и в советский период. В частности, в УК РСФСР 1926 г. ${ }^{2}$ в качестве одного из проявлений контрреволюционной деятельности признавалось участие в организации, образованной для подготовки или совершения одного из преступлений, предусмотренных главой о государственных преступлениях (ст. 58 УК).

В дальнейшем законодатель определил такие организации как антисоветские, имеющие своей целью совершить особо опасные государственные преступления (ст. 9 Закона СССР от 25.12.1958 «Об уголовной ответственности за государственные преступления» ${ }^{3}$ ). Как уже было сказано, при сравнении признаков такие общества могут рассматриваться в современном уголовном законодательстве в качестве аналога террористического сообщества (ст. 205 УК).

Значительным шагом вперед в развитии уголовно-правового регулирования преступных объединений стало введение в Уложение о наказаниях уголовных и исправительных 1845 г. понятия шайки, которой признавалась группа лиц, составленная для совершения даже одного преступления, но заранее оговоренного соучастниками.

\footnotetext{
${ }^{1}$ Уголовное уложение 22 марта 1903 г. СПб., 1904. С. 189.

${ }^{2}$ СУ РСФСР. 1926. № 80. Ст. 600.

${ }^{3}$ BBC CССР. 1959. № 1. Ст. 8.
} 
В Уголовном уложении 1903 г. законодатель конкретизировал цель создания шайки - совершение нескольких тяжких преступлений или преступлений, особо указанных в законе (ст. 52). Другими словами, шайка приобрела признак устойчивости, характерный для организованных форм соучастия, целью которых является осуществление преступной деятельности.

Понятие шайки продолжило свое существование в советский период отечественного законотворческого процесса (Руководящие начала по уголовному праву РСФСР 1919 г., УК РСФСР 1922 г. и УК РСФСР 1926 г.). Совершение преступления шайкой являлось квалифицирующим признаком составов преступлений, в частности грабежей, разбоев и др. Различие шайки и банды заключалось в вооруженности последней. Поэтому сравнительный анализ положений УК РСФСР 1922 г., УК РСФСР 1926 г. и УК РФ 1996 г. позволяет соотнести понятие шайки с понятием организованной группы, которая также отличается от банды признаком вооруженности и является квалифицирующим признаком определенных составов преступлений.

В послевоенное время важное значение имели два изданных Указа Президиума Верховного Совета СССР от 04.06.1947 «Об уголовной ответственности за хищение государственного или общественного имущества» и «Об усилении охраны личной собственности граждан» ${ }^{1}$, установившие уголовную ответственность за хищение государственного, общественного и личного имущества граждан. В данных указах в качестве квалифицирующего признака хищений предусматривалось совершенное организованной группой (шайкой) или «воровской шайкой» преступление. Такая формулировка ставила знак равенства между организованной группой и шайкой, а признак организованности отличал их от простой преступной группы лиц [7, с. 11].

В постановлении Пленума Верховного Суда СССР от 19.03.1948 № 6/4/У «О применении Указов от 4 июня 1947 г.» разъяснялось, что «под организованной группой или шайкой следует понимать группу из двух или более лиц, предварительно сорганизовавшихся для совершения одного или нескольких хищений» ${ }^{2}$. Однако уже в последующих законодательных актах понятие шайки перестало использоваться.

Другим видом преступного объединения в отечественном уголовном законодательстве традиционно выступала банда, уголовно-правовое понятие которой введено уже в советский период.

${ }^{1}$ ВВС СССР. 1947. № 19.

2 Уголовный кодекс РСФСР редакции 1926 г.: офиц. текст с изменениями на 1 августа 1948 г. и с приложением постатейно-систематизированных материалов. M., 1948. C. 113. 
A. Н. Монхондонов. Исторические аспекты криминализации создания, руководства и участия в преступных сообществах, организациях и иных объединениях

Если в Руководящих началах по уголовному праву РСФСР 1919 г. банда рассматривалась как синоним группы лиц, шайки и толпы, основным признаком которых было совершение преступления сообща (ст. 21), то в УК РСФСР 1922 г. законодатель уже конкретизировал банду как вооруженную шайку, заложив определяющий признак этого преступного объединения - вооруженность (ст. 76). Также, помимо признака вооруженности, для банды стала формироваться специальная цель, которая получила свое дальнейшее развитие в УК РСФСР 1926 г. В частности, кроме цели нападения на советские и частные учреждения и отдельных граждан, остановки поездов и разрушения железнодорожных путей и иных средств сообщения и связи (ст. 59), для вооруженных банд предусматривалась контрреволюционная цель при организации вооруженных восстаний или вторжении на советскую территорию, а равно участие во всякой попытке в тех же целях захватить власть в центре и на местах или насильственно отторгнуть от РСФСР какую-либо часть ее территории, или расторгнуть заключенные ею договоры (ст. 58).

В контексте исследования представляет интерес определение Судебной коллегии по уголовным делам Верховного суда СССР от 29 июня 1946 г., согласно которому группу следует признавать устойчивой, если «совершение преступлений предполагалось участниками группы не в виде одного только намеченного акта нападения, после чего группа должна была прекратить свое существование, а в виде постоянной или временной деятельности, рассчитанной на неоднократное совершение преступных действий» [1, с. 18].

В очередной раз цель бандитизма трансформировалась в Законе СССР от 25.12.1958 «Об уголовной ответственности за государственные преступления» ${ }^{1}$, согласно которому целью организации вооруженных банд признавалось нападение на государственные, общественные учреждения или предприятия либо на отдельных лиц, а равно участие в таких бандах и в совершаемых ими нападениях (ст. 14). Фактически в таком же виде статья о бандитизме в дальнейшем введена в УК РСФСР 1960 г.

В принятом в 1996 г. УК РФ в связи с историческими изменениями государственных и общественных отношений, а также приоритетов уголовно-правового регулирования целью создания банды названы нападения на граждан или организации (ст. 209 УК). Кроме того, законодатель ввел в понятие банды признак устойчивости, который характерен для организованных форм соучастия.

Федеральным законом от 1 июля 1994 г. № 10-Ф3 «О внесении изменений и дополнений в Уголовный кодекс РСФСР и Уголовно-

${ }^{1}$ BBC CССР. 1959. № 1. Ст. 8. 
процессуальный кодекс РСФСР» ${ }^{1}$ УК РСФСР 1960 г. был дополнен ст. 17, которой в качестве квалифицирующего признака ряда составов преступлений вводилось совершение преступления организованной группой.

В УК РФ 1996 г. начала формироваться современная система преступных объединений, за создание, руководство и участие в которых предусматривалась ответственность. Так, вопросам соучастия посвящена отдельная глава 7 (ст. 32-36), в которой дано определение понятия соучастия в преступлении, регламентированы виды соучастников, их ответственность, а также совершение преступления группой лиц, группой лиц по предварительному сговору, организованной группой или преступным сообществом (преступной организацией).

В Особенной части УК законодателем криминализированы создание, руководство и (или) участие в таких объединениях, как незаконное вооруженное формирование (ст. 208 УК), банда (ст. 209 УК), преступное сообщество (преступная организация) (ст. 210 УК), а также в объединении, посягающем на личность и права граждан (ст. 239 УК).

В 2002 г. в связи с принятием Федерального закона «О противодействии экстремистской деятельности» в УК введены статьи 282 и 282, предусматривающие ответственность за организацию экстремистского сообщества и организацию деятельности экстремистской организации соответственно ${ }^{2}$.

В 2012 г. внесены изменения в ст. 239 УК, предусматривающие ответственность за создание некоммерческой организации, посягающей на личность и права граждан ${ }^{3}$.

В 2013 г. в УК внесены изменения, касающиеся ответственности за создание, руководство и участие в террористическом сообществе (ст. 205 УК) и за организацию деятельности террористической организации и участие в деятельности такой организации (ст. 205 УК) 4

Как следствие, в настоящее время в Особенной части УК сформировался своего рода перечень сообществ, организаций и иных объединений, за создание, руководство и участие в которых установлена уголовная ответственность независимо от совершения их участниками конкретных преступлений: террористическое сообщество (ст. 205), террористическая организация (ст. 205), незаконное вооруженное формирование (ст. 208), банда (ст. 209), преступное сообщество (преступная организация) (ст. 210), некоммерческая организация, посягающая на личность и права

${ }^{1}$ СЗ РФ. 1994. № 10. Ст. 1109.

${ }^{2}$ СЗ РФ. 2002. № 30. Ст. 3029.

${ }^{3}$ СЗ РФ. 2012. № 30. Ст. 4172.

${ }^{4}$ СЗ РФ. 2013. № 44. Ст. 5641. 
A. Н. Монхондонов. Исторические аспекты криминализации создания, руководства и участия в преступных сообществах, организациях и иных объединениях

граждан (ст. 239), экстремистское сообщество (ст. 282), экстремистская организация (ст. 282).

История возникновения и развития законодательства о преступных объединениях на фоне эволюции уголовно-правового института соучастия в преступлении позволяет условно обозначить несколько этапов его становления.

На первом этапе законодатель разделил преступления, совершенные одним лицом, и преступления, совершенные группой лиц. Установление более строгого наказания за групповые преступления отразило их повышенную общественную опасность (Русская Правда, Псковская судная грамота, Судебник 1497 г. и др.).

Второй этап ознаменовался выделением таких видов групп и преступных объединений, как скоп, шайка, банда, толпа, заговор и др. Особенностью законодательных актов было то, что они не содержали определений групп и объединений, ограничиваясь лишь их перечислением (Судебник 1550 г., Соборное уложение 1649 г., Воинский устав Петра Первого (артикул) 1715 г., Уложение о наказаниях уголовных и исправительных 1845 г. (в редакции 1885 г.).

На третьем этапе законодатель в качестве определяющих признаков конкретного преступного объединения (банды, контрреволюционной (антисоветской) организации) устанавливал цели их создания (Уголовное уложение 1903 г., Руководящие начала по уголовному праву 1919 г., УК РСФСР 1922 г. и УК РСФСР 1926 г., Основы уголовного законодательства Союза ССР и союзных республик, утвержденные Законом СССР от 25.12.1958, УК РСФСР 1960 г.).

И, наконец, на четвертом этапе в уголовном законе закреплены формы соучастия в преступлении, криминализирована организация незаконного вооруженного формирования, преступного сообщества (преступной организации), экстремистского и террористического сообществ, деятельности экстремистской и террористической организаций (Основы уголовного законодательства Союза ССР и республик 1991 г., УК РФ 1996 г.). Данный этап характеризуется, с одной стороны, криминализацией современных видов преступных объединений, с другой - смешением критериев классификаций, отсутствием системного и унифицированного подхода к выделению в Общей и Особенной частях УК РФ форм соучастия и видов преступных объединений.

В целом анализ истории отечественного уголовного законодательства о преступных объединениях свидетельствует о том, что преступления в их составе совершались на всех этапах развития общества, однако уголовно-правовая оценка общественной опасности создания, руководства и участия в преступных объединениях давалась по мере совершенствования 
государственных институтов и нормативного регулирования. Вместе с тем характерной особенностью указанных законодательных актов, в том числе УК РФ, является выделение видов и признаков конкретных преступных объединений без разработки системных положений, регламентирующих соучастие в преступной деятельности и его формы, на основе которых криминализирована деятельность преступных объединений.

\section{Литература}

1. Гришко Е. Понятие преступного сообщества (преступной организации) и его место в институте соучастия // Уголовное право. 2000. № 2. C. 18 .

2. Ковалев М. И. Соучастие в преступлении. Ч. 1. Понятие соучастия. Свердловск, 1960. 288 с.

3. Российское законодательство $\mathrm{X}-\mathrm{XX}$ веков: в 9 т. / под общ. ред. О. И. Чистякова. Т. 1. Законодательство Древней Руси / отв. ред. В. Л. Янин. M., 1984. $432 \mathrm{c.}$

4. Российское законодательство $\mathrm{X}-\mathrm{XX}$ веков: в 9 т. / под общ. ред. О. И. Чистякова. Т. 2. Законодательство периода образования и укрепления Русского централизованного государства / отв. ред. А. Д. Горский. М., 1985. $520 \mathrm{c}$.

5. Российское законодательство X-XX веков: в 9 т. / под общ. ред. О. И. Чистякова. Т. 3. Акты Земских соборов / отв. ред. А. Г. Маньков. М., $1985.512 \mathrm{c}$.

6. Российское законодательство X-XX веков: в 9 т. / под общ. ред. О. И. Чистякова. Т. 5. Законодательство периода расцвета абсолютизма / отв. ред. Е. И. Индова. М., 1987. 528 с.

7. Попова О.А. Проблемы дифференциации ответственности за бандитизм (исторический и уголовно-правовой аспекты): дис. ... канд. юр. наук. Екатеринбург, 2001. С. 11. 
A. Н. Монхондонов. Исторические аспекты криминализации создания, руководства и участия в преступных сообществах, организациях и иных объединениях

\title{
HISTORICAL ASPECTS OF CRIMINALIZATION OF CREATION, MANAGEMENT AND PARTICIPATION IN CRIMINAL COMMUNITIES, ORGANIZATIONS AND OTHER ASSOCIATIONS
}

\author{
A. N. Mondokhonov \\ Cand. Sci. (Law), First Deputy Prosecutor \\ of the Republic of Khakassia, \\ Prosecutor's Office of the Republic of Khakassia \\ 80 Chertygasheva St., Abakan 665017, Russia \\ E-mail: andrmon1@yandex.ru
}

In the article, the author highlights the historical aspects and stages of criminalization of the creation, management and participation in criminal communities, organizations and other associations against the background of the evolution of the criminal law institution of complicity in crime. At the first stage, the legislator identified crimes committed by one person and crimes committed as part of a group of persons.at the second stage, various types of criminal groups and associations (osprey, gang, gang, conspiracy) were identified. The third stage was characterized by the establishment of a criterion for distinguishing criminal associations in the form of the purpose of their creation. At the fourth stage, a modern institution of complicity in crime was formed, on the basis of which the organization of criminal, terrorist and extremist communities, as well as terrorist, extremist and non-profit organizations and other associations (gangs, illegal armed groups) was criminalized.

Keywords: criminal associations; organization; community; complicity; organized group; gang; gang. 